\title{
ANALISIS PENERAPAN E-GOVERNMENT DAN DAMPAKNYA PADA KINERJA DAN PELAYANAN PUBLIK DI KANTOR IMIGRASI KELAS I BANDAR LAMPUNG
}

\author{
Maria Elina $^{(1)}$, Ryorycardo Bangsawan ${ }^{(2)}$ \\ Fakultas Ekonomi Universitas Sang Bumi Ruwa Jurai \\ maria.elina@fe.saburai.ac.id, bangsawan.ryorycardo@gmail.com
}

\begin{abstract}
Abstrak. E-Government adalah tata kelola pemerintah dengan menggunakan teknologi informasi dan khususnya internet sebagai salah satu alat pemerintah untuk meningkatkan pelayanan pemerintah kepada warga Negara, lembaga swasta dan lembaga pemerintahan lain yang saling berinteraksi. Permasalahan dalam penelitian ini adalah penggunaan E-Government di Provinsi Lampung khususnya di Kota Bandar Lampung masih sangat rendah, proses pelayanan terkesan kurang baik karena banyak keluhan dari masyarakat serta tidak semua masyarakat paham dalam penggunaan system pendaftaran online dan teknologi. Tujuan dari penelitian ini adalah untuk mengetahui proses, dampak, serta kendala- kendala yang dihadapi dalam penerapan E-Government di Kantor Imigrasi Kelas I Bandar Lampung. Penelitian ini merupakan penelitian kualitatif, yaitu dengan cara menafsirkan, menginterprestasikan, dan mengklasifikasikan dengan menggunakan kerangka teori dan kerangka konsep yang hasilnya diuraikan dan dijelaskan kedalam bentuk kalimat yang jelas, teratur, logis dan efektif. Penelitian ini mengambil 15 orang responden,yaitu pegawai Kantor Imigrasi, dan masyarakat sebagai pemohon pembuatan paspor. Hasil dari penelitian ini yaitu, penggunaan E-office dan pendaftaran paspor secara online merupakan salah satu inovasi yang dilakukan oleh pemerintah guna meningkatkan pelayanan di Kantor Imigrasi Kelas I Bandar Lampung. Proses ini sudah berjalan dengan cukup baik meski terdapat beberapa kendala. Dampak dari penerapan EGovernment adalah adanya efisiensi waktu dalam penyelesaian pekerjaan sehingga tercipta peningkatan pelayanan publik kepada masyarakat.
\end{abstract}

Kata kunci: E-Government, Kinerja, Pelayanan, Publik.

\section{PENDAHULUAN}

Sesuai dengan Pembukaan UndangUndang Dasar Negara Republik Indonesia Tahun 1945, disebutkan bahwa pemerintah negara Indonesia memiliki kewajiban untuk melindungi segenap bangsa dan seluruh tumpah darah Indonesia serta memajukan kesejahteraan umum. Salah satu tugas negara adalah memberikan pelayanan kepada masyarakat dalam bentuk pelayanan jasa maupun penyediaan fasilitas. Pelayanan umum merupakan suatu indikator tingkat kemajuan suatu negara. Oleh karena itu, bila suatu negara berada dalam posisi menuju kemajuan, hal utama yang perlu diperhatikan adalah pelayanan umum pada negara tersebut.

Pemerintah selaku penyedia jasa dituntut untuk memberikan pelayanan kepada masyarakat melalui instansiinstansi pemerintah yang menyelenggarakan pelayanan umum, sebagai bentuk perwujudan fungsi aparatur negara sebagai abdi masyarakat. Dalam rangka peningkatan pelayanan tersebut, maka setiap instansi pemerintahan yang ada di Indonesia, dituntut untuk melaksanakan e-government dengan memanfaatkan teknologi, agar masyarakat bisa terlayani dengan baik.

Dalam pengembangan e-government di Indonesia sudah dimulai dari jaman pemerintahan Presiden Megawati Soekarnoputri tahun 2003 yang ditandai dengan Inpres No.3 Tahun 2003 Tentang Kebijakan dan Strategi Nasional Pengembangan e-government, mengintruksi kepada pemerintah untuk mengambil langkah- langkah yang diperlukan sesuai 
tugas, fungsi dan kewenangan masingmasing guna terlaksananya pengembangan e-government secara nasional dengan berpedoman pada Kebijakan dan Strategi Nasional Pengembangan e-government.

Berdasarkan

E-government

Development Index (EDGI) hingga akhir 2012 perkembangan e-government di Indonesia masih jauh tertinggal dibandingkan dengan negara-negara lainnya, khususnya di kawasan Asia Tenggara. Indonesia berada di peringkat ke7 diantara negara di kawasan Asia Tenggara dalam laporan survey Persatuan Bangsa Bangsa (2012), di mana EGDI adalah indikator komposit yang mengukur kemauan dan kapasitas administrasi pemerintahan untuk menggunakan teknologi komunikasi dan informasi (TIK) untuk menyediakaan layanan publik.

Berdasarkan hal tersebut, Indonesia merupakan urutan ketujuh yang memanfaatkan teknologi dalam pelayanan yang dilakukan oleh instansi pemerintahan. Artinya, pemanfaatan e-government di Indonesia, masih sangat rendah. Penyebab kurangnya pemanfaatan e-government di Indonesia adalah kurangnya infrastuktur dan aplikasi pendukung teknologi informasi di lingkungan kantor pemerintahan. Adanya budaya dan perilaku pegawai negeri yang masih enggan untuk mulai memanfaatkan teknologi informasi dalam mendukung kegiatan perkantoran juga menjadi masalah pelik yang menghambat perkembangan e-government.

Padahal jika dikaji lebih lanjut, keberadaan $e$ - government yang memanfaatkan e-office ini dapat membantu serta memudahkan instansi pemerintahan dalam menjalankan aktivitas individu atau satuan unit kerja pada pemerintahan itu sendiri. Oleh karena itu, untuk memacu perkembangan $e$-government perlu sebuah komitmen serta inovasi dari teknologi informasi yang dapat memuncul rasa ketertarikan terhadap teknologi yang akan digunakan guna meningkatkan kualitas pelayanan umum.

Pelayanan umum yang berkualitas dan bermutu tinggi menjadi perhatian utama dari organisasi publik. Pelayanan umum adalah kemudahan dalam mengurus kepentingan mendapatkan pelayanan yang wajar, perilaku yang sama tanpa pilih kasih dan perlakuan yang jujur dan terus terang. Pelayanan publik adalah sebagai pemberian layanan keperluan orang atau masyarakat yang mempunyai kepentingan pada organisasi yang sesuai dengan aturan pokok dan tata cara yang telah ditetapkan. pelayanan publik adalah kegiatan yang dilakukan oleh seseorang atau sekelompok orang dengan landasan faktor material melalui sistem, prosedur dan metode tertentu dalam usaha memenuhi kepentingan oranglain sesuai dengan haknya.

Berjalannya waktu kemajuan teknologi informasi pemerintah memberikan pelayanan dengan memanfaatkan perkembangan teknologi informasi yang semakin canggih. Dengan memanfaatkan kemajuan teknologi informasi yang semakin canggih untuk memberikan nilai tambah pada pelayanan publik yang diberikan oleh pemerintah. Pada hal ini salah satunya meliputi pelayanan dalam bidang keimigrasian di Kantor Imigrasi. Kantor Imigrasi melayani berbagai macam pelayanan salah satunya yaitu pembuatan paspor.

Paspor merupakan sebuah dokumen resmi yang dikeluarkan oleh pejabat yang memiliki wewenang dari suatu negara yang berisi identitas pemilik paspor yang meliputi foto pemegang, tanda tangan, tempat dan tanggal lahir, informasi kebagsaan dan informasi lainnya untuk melakukan perjalanan antar negara dengan jangka waktu yang ditentukan. Paspor biasanya diperlukan saat tiba diperbatasan suatu negara untuk memperlihatkan 
identitas sebagai warga asing bagi negara yang kunjungi.

Secara umum, kondisi pelayanan pembuatan paspor saat ini masih belum bisa mencapai pelayanan yang baik. Banyaknya keluhan yang terjadi pada masyarakat terkait pelayanan pada Kantor Imigrasi dikarenakan adanya birokrasi yang berbelitbelit, lambat, bahkan melelahkan. Masyarakat yang ingin membuat paspor, merasa tidak mendapatkan pelayanan yang memadai, harus lama mengantri, bahkan harus menunggu proses penyelesaian paspor hingga berminggu-minggu.

Kondisi tersebut menuntut pelayanan di Kantor Imigrasi untuk memberikan pelayanan yang efektif, tepat waktu sesuai waktu yang telah ditentukan, memberikan informasi yang jelas terkait persyaratan, sederhana dalam prosedur, mudah dipahami serta tidak berbelit-belit, adanya kesesuaian biaya, serta respon yang cepat dan tanggap dalam pelayanan.

Terkait hal tersebut, saat ini pemerintah memberikan solusi untuk masyarakat yang ingin membuat paspor, yaitu dengan melakukan pendaftaran online yang dimaksudkan agar dapat mempersingkat waktu serta memberikan kemudahan kepada mayarakat. Masyarakat yang ingin membuat paspor hanya perlu mengisi aplikasi pembuatan maupun perpanjangan paspor tanpa harus lama mengantri dengan sistem online ini, meskipun tetap harus datang ke Kantor Imigrasi guna verifikasi berkas, wawancara, pengambilan foto, maupun sidik jari.

Keberadaan sistem pendaftaran online dimaksudkan untuk mengurangi antrian panjang yang biasa terjadi pada pendaftaran secara manual, dengan demikian, diharapkan hal ini dapat meningkatkan kualitas pelayanan di Kantor Imigrasi. Pendaftaran online ini merupakan upaya pemerintah untuk mewujudkan pelaksanaan e-government khususnya untuk Kantor Imigrasi.
Layanan penerbitan paspor secara online terdapat 2 (dua) jenis, antara pra permohonan dan status permohonan. Pra permohonan berfungsi sebagai Penerbitan paspor secara online sedangkan status permohonan berfungsi sebagai untuk melihat informasi kapan pendaftar pembuatan paspor secara online harus datang ke kantor Imigrasi data yang online dengan data yang asli.

Tujuan dilakukannya terobosan ini adalah untuk meningkatkan kepastian layanan pembuatan paspor kepada masyarakat yang dinilai semakin peka terhadap perlakuan pelayanan dari petugas dan infrastruktur pelayanan baik yang positif maupun negatif. Tujuan lainnya adalah untuk mencapai sasaran dan tujuan dari organisasi yang telah ditetapkan sebelumnya seperti halnya melayani masyarakat dengan baik serta memberikan kemudahan dalam setiap proses pelayanan yang berlangsung.

Selain itu, penerapan e-government di Kantor Imigrasi diwujudkan dengna pelaksanaan e-office. Sistem perkantoran elektronik (Electronic Office, e-Office) merupakan aplikasi perkantoran yang menggunakan media elektronik yaitu dengan mengganti proses administrasi berbasis manual ke proses berbasis elektronik dengan memanfaatkan fasilitas jaringan lokal.

Aplikasi perkantoran diharapkan mampu memberikan solusi untuk setiap permasalahan administrasi yang dihadapi, seperti mengatasi masalah perbedaan waktu, tanggapan atau responsi yang lebih cepat, menyediakan informasi yang akurat dan mampu menjangkau lokasi jarak jauh. E-office dimaksudkan untuk dapat memaksimalkan e-government seiring dengan kebijakan reformasi birokrasi yang mulai berlaku di Indonesia.

Berdasarkan hasil pra-riset yang telah dilakukan, masih banyak hambatan yang terjadi dalam penerapan e-government di 
Kantor Imigrasi Kelas I Bandar Lampung. Sistem e-office dan pendaftaran online telah mulai diberlakukan tahun 2017, namun sistem ini belum sepenuhnya berjalan.

Pegawai Kantor Imigrasi masih belum menerpakan e-office sepenuhnya karena terkendala pemahaman teknologi yang terbatas. Begitu pula dengan sistem pendaftaran online yang dinilai oleh masyarakat terlalu rumit karena tidak semua masyarakat mengerti tentang sistem pendaftaran online dan teknologi. Oleh karena itu, perlu diadakannya sosialisasi tentang sistem ini serta langkah-langkah penggunaannya agar dapat dengan mudah dimengeti dan diterapkan baik oleh pegawai Kantor Imigrasi sendiri, dan juga masyarakat.

Berdasarkan latar belakang tersebut di atas, peneliti tertarik untuk melalukan penelitian lebih lanjut dengan judul:

"Analisis Penerapan E-Government dan Dampaknya Pada Kinerja dan dan Pelayanan Publik di Kantor Imigasi Kelas I Bandar Lampung".

\section{KAJIAN TEORI}

\section{Pengertian E-government}

Menurut Bank Dunia di dalam Samodra Wibawa (2009), E- government adalah penggunaan teknologi informasi oleh instansi pemerintah seperti wide area Networks (WAN) internet, moble competing, yang dapat digunakan untuk membangun hubungan dengan masyarakat, dunia usaha dan instansi pemerintah lainnya.

Menurut The Worid Bank Group di dalam Falih Suaedi dan Bintoro Wardianto (2010), E-government ialah sebagai upaya pemamfaatan informasi dan teknologi komunikasi untuk meningkatkan efesiensi dan efektivitas, transfaransi dan akuntabilitas pemerintah dalam memberikan pelayanan publik secara lebih baik. Kemudian menurut Depkomenfo di dalam Samodra Wibawa (2009), mendefinisikan E-goverment adalah pelayanan publik yang diselenggarakan melalui situs pemerintah dimana domain yang digunakan juga menunjukkan domain pemerintah Indonesia yakni go.id.

Menurut Clay G. Weslatt di dalam Samodra Wibawa (2009), E- goverment adalah menggunakan teknologi informasi dan komunikasi untuk mempromosikan pemerintah yang lebih efisien dan penekanan biaya yang efektif, kemudian pasilitas layanan terhadap masyarakat umum dan membuat pemerintah lebih bertanggung jawab kepada masyarakat.

Sedangkan dalam buku E-goverment In Action yang dikutip oleh Samodra Wibawa (2009) menguraikan E-goverment adalah suatu usaha menciptakan suasana penyelanggaraan pemerintah yang sesuai dengan objektif bersama (Shared goals) dari sejumlah komunitas yang berkepentingan, oleh karena itu visi yang dicanangkan juga harus mencerminkan visi bersama dari pada stakholeder.

\section{Pengertian Kinerja}

Menurut Mangkunegara (2013), kinerja adalah hasil kerja secara kualitas dan kuantitas yang dicapai oleh seseorang pegawai dalam melaksanakan tugasnya sesuai dengan tanggung jawab yang diberikan kepadanya.

Ditambahkan oleh Umam (2012), kinerja adalah sebagai perluasan dari bertemunya individu dan harapan tentang apa yang seharusnya dilakukan individu terkait dengan satu peran dan kinerja tersebut merupakan evaluasi terhadap 
berbagai kebiasaan dalam organisasi yang membutuhkan standarisasi yang jelas.

Sedangkan menurut Wilson (2013) kinerja adalah hasil pekerjaan yang dicapai seseorang berdasarkan persyaratanpersyaratan pekerjaan (Job Requirement). Suatu pekerjaan mempunyai persyaratan tertentu untuk dapat dilakukan dalam mencapai tujuan yang disebut juga sebgai standar pekerjaan (Job Standar). Standar Kinerja adalah tingkat yang diharapkan suatu pekerjaan tertentu untuk dapat diselesaikan, dan merupakan perbandingan atas tujuan atau target yang ingin dicapai.

Fahmi (2011) berpendapat bahwa, kinerja adalah hasil yang diperoleh oleh suatu organisasi tersebut baik bersifat profit oriented dan non profit oriented yang dihasilkan selama satu periode waktu. Berdasarkan beberapa pendapat diatas, dapat disimpulkan bahwa kinerja adalah kerja seseorang dalam sebuah organisasi perusahaan berdasarkan atas kemampuan dan pengetahuan. Hasil kerja yang dicapai oleh seseorang haruslah dapat memberikan kontribusi yang penting bagi perusahaan yang dilihat dari segi kualitas dan kuantitas yang dirasakan oleh perusahaan dan sangat besar manfaatnya bagi kepentingan perusahaan dimasa sekarang dan yang akan datang.

\section{Faktor-Faktor yang Mempengaruhi Kinerja}

Menurut Sutrisno (2013) faktor-faktor yang mempengaruhi kinerja adalah sebagai berikut, yaitu:

1. Efektivitas dan efesiensi

Dalam hubungannya dengan kinerja organisasi, maka ukuran baik buruknya kinerja diukur oleh efektivitas dan efesiensi. Masalahnya adalah bagaimana proses terjadinya efisiensi dan efektivitas organisasi. Dikatakan efektif bila mencapai tujuan, dikatakan efesien bila hal itu memuaskan sebagai pendorong mencapai tujuan, terlepas apakah efektif atau tidak.

2. Otoritas dan Tanggung Jawab

Dalam organisasi yang baik wewenang dan tanggung jawab telah didelegasikan dengan baik, tanpa adanya tumpang tindih tugas. Kejelasan wewenang dan tanggung jawab setiap orang dalam suatu organisasi akn mendukung kinerja karyawan tersebut. Kinerja karyawan akan dapat terwujud bila karyawan mempunyai komitmen dengan organisasinya dan ditunjang dengan disiplin kerja yang tinggi.

\section{Disiplin}

Secara umum, disiplin menunjukkan suatu kondisi atau sikap hormat yang ada pada diri karyawan terhadap peraturan dan ketetapan perusahaan. Disiplin meliputi ketaatan dan hormat terhadap perjanjian yang dibuat antara perusahaan dan karyawan. Dengan demikian, bila peraturan atau ketetapan yang ada dalam perusahaan diabaikan atau sering dilanggar, maka karyawan mempunyai disiplin yang buruk. Sebaliknya, pbila karyawan tunduk pada ketetapan perusahaan, manggambarkan adanya kondisi disiplin yang baik.

4. Inisiatif

Inisiatif seseorang berkaitan dengan daya pikir, kreatifitas dalam bentuk ide untuk merencanakan suatu yang berkitan dengan tujuan organisasi. Setiap inisiatif sebaiknya mendapat perhatian atau tanggapan positif dari atasan, kalau memang dia atasan yang baik. Atasan yang buruk akan selalu mencegah inisiatif bawahannya, lebihlebih bawahan yang kurang disegani. 
Dengan perkataan lain, inisiatif karyawan yang ada didalam organsasi merupakan daya dorong kemajuan yang akhirnya akan memengaruhi kinerja.

5. Pengawasan

Pengawasan dapat didefinisikan sebagai cara suatu organisasi mewujutkan kinerja yang efektif dan efesien, serta leih jauh mendukung terwujutnya visi dan misi organisasi.Pengawasan adalah sebagai proses untuk menjamin bahwa tujuantujuan organisasi dan manajemen tercapai.

\section{Motivasi}

Motivasi adalah suatu kondisi yang mendorong atau yang menjadi sebab seseorang melakukan suatu kegiatan/perbuatan yang berlangsung secara sadar dimana kebutuhankebutuhan mendorong seseorang untuk melakukan serangkaian kegiatan yang mengarah ketercapainya tujuan tertentu.

\section{Pengertian Pelayanan Publik}

Istilah pelayanan berasal dari kata "layan" yang artinya menolong menyediakan segala apa yang diperlukan oleh orang lain untuk perbuatan melayani. Dikemukakan oleh Sinambela (2010), pada dasarnya setiap manusia membutuhkan pelayanan, bahkan secara ekstrim dapat dikatakan bahwa pelayanan tidak dapat dipisahkan dengan kehidupan manusia. Sementara itu, istilah publik berasal dari Bahasa Inggris "public" yang berarti umum, masyarakat, negara. Kata public sebenarnya sudah diterima menjadi Bahasa Indonesia Baku menjadi Publik yang memiliki arti umum, orang banyak, ramai.
Beberapa pakar yang memberikan pengertian mengenai pelayanan publik diantaranya adalah Agung kurniawan (2005), yang mengatakan bahwa pelayanan publik adalah pemberian pelayanan (melayani) keperluan orang lain atau masyarakat yang mempunyai kepentingan pada organisasi itu sesuai dengan aturan pokok dan tata cara yang ditetapkan.

Ratminto (2005) mendefinisikan bahwa Pelayanan publik atau pelayanan umum dapat didefenisikan sebagai segala bentuk jasa pelayanan, baik dalam bentuk barang publik maupun jasa publik yang pada prinsipnya menjadi tanggung jawab dandilaksanakan olehinstansi pemerintah di pusat, didaerah, dan dilingkungan Badan Usaha Milik Negara atau Badan Usaha Milik Daerah, dalam rangkaupaya pemenuhan kebutuhan masyarakat maupun dalam rangkapelaksanaan ketentuan peraturan perundang-undangan.

Menurut Sinambela (2010),pelayanan adalah setiap kegiatan yang dilakukan oleh pemerintah disetiap kegiatan yang menguntungkan dalam suatu kumpulan atau kesatuan, dan menawarkan kepuasan meskipun hasilnya tidak terikat pada suatu produk secara fisik.

Selanjutnya dalam Keputusan Menteri Pendayagunaan Aparatur Negara Nomor 63 Tahun 2003 telah dijelaskan bahwa pengertian pelayanan publik adalah segala kegiatan pelayanan yang dilaksanakan oleh penyelenggara pelayanan publik sebagai upaya pemenuhan kebutuhan penerima pelayanan maupun pelaksanaan kebutuhan peraturan perundangundangan. Sedangkan penyelenggara pelayanan publik dalam Keputusan Menteri Pendayagunaan Aparatur Negara No.

63 tahun 2003 diuraikan bahwa Instansi Pemerintah sebagai sebutan kolektif yang meliputi Satuan Kerja/ satuan organisasi Kementerian, Departemen, Lembaga Pemerintah Non Departemen, 
Kesekretariatan Lembaga Tertinggi dan Tinggi Negara, dan Instansi Pemerintah lainnya, baik pusat maupun Daerah termasuk Badan Usaha Milik Negara, Badan Usaha Milik Daerah, Menjadi penyelenggara pelayanan publik. Sedangkan pengguna jasa pelayanan publik adalah orang, masyarakat, instansi pemerintah dan badan hukum yang menerima layanan dari instansi pemerintah (Dwiyanto, 2014).

Jadi dapat disimpulkan bahwa, sebagai pemberian layanan atau melayani keperluan orang atau masyarakat dan/atauorganisasi lain yang mempunyai kepentingan pada organisasi itu, sesuai dengan aturan pokok dan tata cara yang ditentukan dan ditujukan untuk memberikan kepuasan kepada penerima pelayanan.

\section{METODE PENELITIAN}

\section{Objek Penelitian}

Penelitian dilakukan di Kantor Imigrasi Kelas I Bandar Lampung sebagai objek penelitian, yang beralamat di Jalan Cut Meutia Kecamatan Teluk Betung Kelurahan Sumur Batu Bandar Lampung. Penelitian dilakukan pada bulan Januari 2017.

\section{Metode Penelitian}

Metode yang digunakan pada penelitian ini adalah penelitian deskriptif analisis. Deskriptif penelitian ini terbatas pada usaha mengungkapkan suatu masalah atau keadaan atau peristiwa sebagaimana adanya sehingga bersifat sekedar untuk mengungkapkan. Hasil penelitian ini memberikan gambaran secara obyektif tentang keadaan sebenarnya dari obyek yang diselidiki. penelitian yang bersifat deskriptif analisis bertujuan menggambarkan kenyataan-kenyataan yang ada atau realitas dan menggambarkan obyek yang menjadi pokok permasalahan.

\section{Teknik Pengumpulan Data}

Untuk mendapatkan dan mengumpulkan data yang sesuai dengan kebutuhsn dalam penelitian ini, maka metode pengumpulan data yang digunakan adalah sebagai berikut :

1. Data Primer

Data Primer adalah data yang diperoleh secara langsung dari responden dan narasumber tentang objek yang diteliti. Yaitu dengan wawancara langsung dengan Kantor Imigrasi Kelas I Bandar Lampung.

2. Data Sekunder

Data sekunder yaitu data teoritis yang diperoleh melalui studi kepustakaan dimaksudkan untuk lebih menetapkan kebenaran data atau informasi yang diperoleh ditempat penelitian, sehingga kebenaran tulisan meiliki validitas yang tinggi.

Dalam penelitian ini, teknik pengumpulan data yang dilakukan adalah dengan cara :

1) Wawancara

Teknik ini dijalankan dengan cara sumber secara bebas terpimpin dengan melakukan tanya jawab di Kantor Imigrasi Kelas I Bandar Lampung.

2) Studi Kepustakaan

Yaitu penelitian yang dilakukan dengan mengumpulkan data atau pendapat para ahli atau ilmuwan yang berhubungan denagn obyek yang diteliti, dari buku literature atau lainnya yang dapat mendukung peneliti dalam membahas masalah yang dihadapi. 
3) Observasi

Teknik ini dilakukan dengan mengadakan pengamatan secara langsung terhadap obyek yang diteliti. Dalam hal ini peneliti terjun langsung di Kantor Imigrasi Kelas I Bandar Lampung.

4) Dokumentasi

Dokumentasi mengumpulkan dengan cara dokumen-dokumen yang ada yang memiliki keterkaitan dengan penelitian yang sedang dilakukan.

\section{Teknik Sampel}

Populasi dalam penelitian ini adalah unit yang ada sangkut pautnya dengan tanggung jawab Kepala Kantor Imigrasi Kelas I Bandar Lampung, seperti kepada Kepala Kantor Imigrasi Kelas I Bandar Lampung, Kasi Informasi dan Sarana Komunikasi Keimigrasian, serta masyarakat yang membuat paspor di Kantor Imigrasi Kelas I Bandar Lampung.

\section{Metode Analisis}

Penelitian ini analisis data dilakukan secara kualitatif, yaitu dengan cara menafsirkan, menginterprestasikan, dan mengklasifikasikan dengan menggunakan kerangka teori dan kerangka konsep yang hasilnya diuraikan dan dijelaskan kedalam bentuk kalimat yang jelas, teratur, logis dan efektif sehingga diperoleh gambaran yang jelas, tepat, dan dapat ditarik kesimpulan sehingga dari beberapa kesimpulan tersebut dapat diajukan saran-saran.

\section{HASIL DAN PEMBAHASAN}

Pelayanan publik yang sebaikbaiknya adalah pelayanan yang diproses cepat, tepat dan memberikan hasil akurat serta terpercaya dengan pertanggung jawaban penuh dan dengan ini pelayanan publik telah daitur dalam Undang- Undang Nomor 25 Tahun 2009 tentang pelayanan publik yang menjadi kewajiban pemerintah dalam pemenuhannya. Landasan yuridis tentang kewajiban pemerintah untuk memberikan pelayanan ini kepada masyarakat adalah hak sosial dasar yang dimiliki oleh seluruh masyarakat di Indonesia, dengan atau tanpa diskriminasi atau perbedaan di kehidupan sehati-hari maupun di muka hukum yakni Pasal 18A Ayat (2) dan Pasal 34 Ayat (3) UndangUndang Dasar 1945.

Oleh sebab itu, diterapkan kepada pemerintah Indonesia electronic government atau pemerintahan dengan pengelolan yang berbasis elektronik. Dalam hal ini pemerintah semakin dituntut untuk beralih dari pemerintah tradisional yang identik dengan paper based administration atau pemerintah yang berbasis dengan kertas atau segala sesuatu tugas diselesaikan dengan cara manual, hingga berubah menjadi electronic government administration atau pendigitalan dan segala bidang urusan dan pekerjaan dalam sektor pemerintahan yang di kenal dengan E- Government agar mempermudah pemberian pelayanan kepada masyarakat.

Kantor Imigrasi Kelas I Bandar Lampung telah menerapkan EGovernment dalam bentuk E-office. Penggunaan E-office ini diharapkan dapat membantu mengurangi beban pekerjaan dari masing-masing divisi sehingga semakin meningkatkan pelayanan publik. Selain itu, tujuan yang ingin dicapai dalam penggunaan E-office adalah meminimalisir kesalahan komunikasi antar divisi dan meminimalisir penggunaan kertas sesuai dengan slogan "Go-Green" yang saat ini sedang gencar dicanangkan oleh pemerintah.

Dalam E-Office tidak dikenal tingkatan pengguna (leveling user) sistem. 
Kewenangan yang diberikanadalah spesifik melekat ke jabatan dan fungsi masing-masing pegawai/pejabat. Namun, terdapat fungsi tambahan yang dapat ditambahkan, yaitu:

1. Sekretaris Unit.

2. Pimpinan Unit

3. Pejabat (Eselon II, Eselon III, dan Eselon IV).

4. Pelaksana/Fungsional.

E-Government adalah tata kelola pemerintah dengan menggunankan teknologi informasi dan khususnya internet sebagai salah satu alat pemerintah untuk meningkatkan pelayanan pemerintah kepada warga Negara, lembaga swasta dan lembaga pemerintahan lain yang saling berinteraksi. Penerapan E-Government ini berfaktor karena pemerintahan ingin menyesuaikan diri terhadap zaman dan era modern dan lagi terdapat banyaknya masalah yang mengakar dan mendarah daging pada badan pemerintahan di indonesa yaitu banyaknya kasus korupsi, Kolusi dan nepotisme yang melanda pemerintahan di Indonesia yang mana muncul karena sifat monopoli pemerintah yang ingin memegang kekuasaan seluruh pemerintahan dengan mengendalikan segala potensi yang ada di Negara ini.

Adanya banyak penyalahan gunaan wewenang (Diskresi) oleh pejabat-pejabat pemerintahan dan pejabat publik dengan begitu terbuka lebarnya korupsi dan pungutan liat dalam penurusan perizinan yang dimana terjadi karena prosedur yang panjang dan sangat kompleks. Minimnya kepercayaan masyarakat kepada pemerintahan dan pertanggung jawaban pejabat pemerintahan terlihat pada cara pengambilan keputusan dan tindakantindakan yang dimana dipercayai dengan menerapkan teknologi komunikasi dan informasi kedalam bidang pemerintahan untuk meningkatkan keterbukaan pemerintahan dan partisipasi masyarakat.

Penerapan atau pengimpelemtasian E-Government di Kantor Imigrasi Kelas I Bandar Lampung sudah berjalan dengan baik, yaitu telah mentaati regulasi atau peraturan yang diinstruksikan dari pemerintah pusat untuk memanfaatkan kemajuan teknologi komunikasi da informasi kedalam peroses tata kelola pemerintahan daerah di seluruh Indonesia. Dalam penerapan ini Kantor Imigrasi Kelas I Bandar Lampung telah mencapai nilai cukup baik meski terdapat beberapa kendala.

Namun, karena Indonesia masih baru mengeluarkan instruksi penerapan electronik dalam sistem pemerintahan, maka masih terdapat banyak hal yang harus di perbaiki dalam penerapan ini, terlebih lagi untuk sarana dan prasarana yang akan mendukung jalannya penerapan tersebut dan lagi masih banyak birokrat yang masih membutuhkan pendampingan dalam pengelolaan pemerntahan yang berbasis electronik ini sehingga pemerintah Indonesia bisa menyesuaikan diri terhadap kemanjuan zaman di era globalisasi.

\section{KESIMPULAN}

\section{Kesimpulan}

Berdasarkan hasil penelitian, maka yang dapat penulis simpulkan adalah :

1. Penggunaan E-office dan pendaftaran paspor secara online merupakan salah satu inovasi yang dilakukan oleh pemerintah guna meningkatkan pelayanan di Kantor Imigrasi Kelas I Bandar Lampung. Proses ini sudah berjalan dengan cukup baik meski terdapat beberapa kendala.

2. Dampak dari penerapan E-Government adalah adanya efisiensi waktu dalam penyelesaian pekerjaan sehingga 
tercipta peningkatan pelayanan publik kepada masyarakat.

3. Kendala yang dihadapi dalam penerapan E-Government adalah faktor SDM, ketersediaan server, kurangnya sosialisasi, dan minimnya pengetahuan masyarakat tentang teknologi.

\section{Saran}

Saran yang ingin penulis sampaikan dalam penelitian ini yaitu:

1. Perlu adanya pelatihan lagi agar pegawai lebih bisa dan terus meningkatkan kemampuan dalam mengelola dan memanfaatkan teknologi informasi yang tersedia.

2. Perlu dilakukan sosialisasi yang lebih mendalam kepada masyarakat mengenai pendaftaran online seperti menjelaskan secara langsung kepada masyarakat yang bersangkutan.

3. Perlu adanya penambahan pegawai dengan umur yang lebih muda dan gesit serta bisa mengoperasikan komputer. Serta perlu peningkatan konektivitas internet agar tidak terdapat kendala lagi dalam pemberian layanan online.

\section{DAFTAR PUSTAKA}

Agung, Kurniawan. 2005. Transformasi Pelayanan Publik. Yogyakarta: Pembaharuan.

Dwiyanto, Agus. 2010. Manajemen Pelayanan Publik: Perduli, Inklusif, dan Kolaboratif. Yogyakarta: Gadjah Mada University Press.

Handoko, Hani. 2012. Manajemen. Yogyakarta: BPFE.
JE, Hosio. 2007. Kebijakan Publik dan Desentralisasi. Yogyakarta: Laksbang.

Keban, M.S. 2000. Administrasi Publik. Teori dan Aplikasi Good Governance. Bandung: Refika Aditama.

Ratminto, dan Atik Septi Winarsih. 2005. Manajemen Pelayanan. Yogyakarta: Pustaka Pelajar.

Sinambela, Lijan Poltak, dkk. 2010. Reformasi Pelayanan Publik, Teori, Kebijakan, dan Implementasi. Jakarta: PT. Bumi Aksara.

Sondang P. Siagian. 2002. Teori Pengembangan Organisasi. Jakarta: Bumi Aksara.

Suaedi, Falih, Wardiyanto, Bintoro. 2010. Revitalisasi Administrasi Negara (Revormasi Birokrasi dan eGovernment). Yogyakarta: Graha Ilmu.

Sutrisno, Edy. 2011. Budaya Organisasi, Edisi Pertama. Cetakan Ke.II. Jakarta: Kencana Prenada Media Group.

Umam, Khaerul. 2012. Manajemen Organisasi. Jakarta: PustakaSetia.

2012.
$\begin{gathered}\text { Organisasi,Cetakan } \\ \text { Pustaka Setia. }\end{gathered}$
Wibawa, Bandung:
Negara Isu-isu Kontemporer.
Yogyakarta: Graha Ilmu.

